Jurnal Keperawatan Silampari

Volume 4, Nomor 1, Desember 2020

e-ISSN: 2581-1975

p-ISSN: 2597-7482

DOI: https://doi.org/10.31539/jks.v4i1.1503

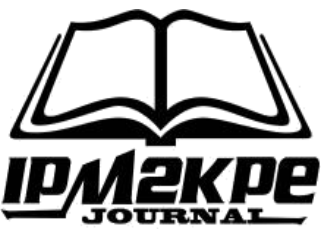

\title{
UPAYA PENINGKATAN CAPAIAN PEMBERIAN ASI EKSKLUSIF (PENDEKATAN SOCIAL COGNITIVE)
}

\author{
Martha Ariana Wijayanti ${ }^{1,}$ Binti Maratus Sholikhah, Ernawaty ${ }^{3}$ \\ Universitas Airlangga ${ }^{1,2,3}$ \\ martha.ariana.w-2018@fkm.unair.ac.id ${ }^{1}$
}

\begin{abstract}
ABSTRAK
Tujuan dari penelitian ini adalah untuk mengidentifikasi pengaruh self efficacy, outcome expectations, socio structural factors dan intention terhadap perilaku ibu bayi (6-24 bulan) dalam pemberian ASI Eksklusif. Desain penelitian yang digunakan adalah observasional dengan pendekatan cross sectional. Hasil penelitian ini menunjukkan bahwa variabel yang mempengaruhi intention ibu untuk memberikan ASI eksklusif adalah sociostructural factors $(\mathrm{p}=0,016)$. Responden yang memiliki intention memberikan ASI eksklusif akan mempunyai perilaku memberikan ASI eksklusif $(p=0,003)$, Sedangkan self efficacy $(p=0,340)$ dan outcome expectation $(\mathrm{p}=0,682)$ tidak mempengaruhi intention ibu. Demikian pula perilaku ibu dalam pemberian ASI eksklusif tidak dipengaruhi oleh self efficacy $(p=0,294)$ dan outcome expectation $(\mathrm{p}=0,586)$. Simpulan, faktor yang mempengaruhi perilaku ibu dalam pemberian ASI eksklusif adalah intention dan socistruktural factors.
\end{abstract}

Kata kunci: ASI Eksklusif, Pendekatan Sosial Kognitif

\section{ABSTRACT}

The purpose of this study was to identify the effect of self-efficacy, outcome expectations, socio-structural factors, and intention on the behavior of the infant-mother (6-24 months) in exclusive breastfeeding. The research design used was observational with a cross-sectional approach. This study indicates that the variables that affect the mother's intention to provide exclusive breastfeeding are socio-structural factors $(p=0.016)$. Respondents who choose to provide exclusive breastfeeding will have the behavior of giving exclusive breastfeeding ( $p=$ 0.003). In contrast, self-efficacy $(p=0.340)$ and outcome expectations $(p=0.682)$ do not affect the mother's intention. Likewise, the mother's exclusive breastfeeding behavior was not influenced by self-efficacy $(p=0.294)$ and outcome expectations $(p=0.586)$. In conclusion, the factors that influence a mother's exclusive breastfeeding behavior are intention and socistructural factors.

Keywords: Exclusive breastfeeding, Cognitive Social Approach

\section{PENDAHULUAN}

WHO (World Health Organization) merekomendasikan pemberian ASI secara eksklusif, ASI eksklusif adalah ASI yang diberikan pada 6 bulan pertama kehidupan tanpa pemberian cairan atau makanan lain, kecuali vitamin, mineral dan obat yang telah diizinkan karena adanya alasan medis (WHO, 2017). 
Penelitian yang dilakukan oleh Muharyani et al., (2018) menjelaskan bahwa lingkungan sekitar ibu dalam hal ini suami, keluarga dan tenaga kesehatan selayaknya menjadi support system terbesar bagi ibu dalam menyusui bayinya. Kurniawati et al., (2020) dalam penelitiannya menjelaskan bahwa dukungan keluarga mempunyai peran penting dalam menunjang keberhasilan ibu dalam pemberian ASI eksklusif. Dengan dukungan keluarga yang baik maka perilaku ibu dalam pemberian ASI eksklusif juga baik, dukungan keluarga yang diberikan kepada ibu akan mempengaruhi kondisi psikologis ibu, sehingga ibu akan mempunyai motivasi yang kuat untuk berusaha mempraktekkan bagaimana menyusui yang benar dan tepat selama 6 bulan. Studi lain juga menyatakan bahwa wanita yang menyusui membutuhkan dukungan dari anggota keluarga (Valizadeh et al., 2018).

Peningkatan program ASI eksklusif adalah salah satu bentuk upaya pemerintah dalam pencapaian Sustainable Development Goals (SDGs). Target ASI eksklusif secara nasional di Indonesia yaitu $80 \%$. ASI eksklusif diberikan kepada bayi karena banyak manfaat antara lain bayi mendapat perlindungan terhadap serangan kuman Clostridium tetani, Difteri, pneumonia, E. Coli, Salmonella, Sigela, Influenza, Streptokokus, Stafilokokus, Virus polio, Rotavirus dan Vibrio colera, serta manfaat lainnya dapat meningkatkan IQ dan EQ anak (Sari \& Farida, 2020).

Persentase pemberian ASI eksklusif masih sangat rendah. Secara global, hanya $40 \%$ bayi di bawah usia 6 bulan yang disusui secara eksklusif (WHO, 2017). Di Indonesia tahun 2016 cakupan keberhasilan pemberian ASI eksklusif masih jauh dari target yaitu sekitar 29,5\% dari 80\% target Nasional (Kemenkes, 2017).

Berdasarkan data profil Dinas Kesehatan Kabupaten Kediri pencapaian pemberian ASI eksklusif pada bayi dari tahun 2015 sampai 2017 mengalami penurunan dari tahun ke tahun dan belum memenuhi target nasional yang telah ditentukan. Capaian ASI eksklusif yang tidak memenuhi target serta mengalami penurunan terbesar dimiliki oleh Puskesmas Blabak yakni sebesar 33,66\%. Program ASI eksklusif di Kabupaten Kediri sebenarnya telah mendapat perhatian dengan adanya seperti kelas edukasi ASI eksklusif bagi ibu hamil, pembentukan tenaga konselor laktasi juga pelatihan bagi tenaga konselor tersebut (dinkes.kedirikab.go.id).

Program yang telah dilaksanakan oleh Dinas Kesehatan Kabupaten Kediri tersebut meningkatkan kemungkinan bahwa penyebab penurunan capaian ASI eksklusif disebabkan oleh perilaku ibu yang tidak memberikan ASI eksklusif kepada bayinya. Pemberian ASI Eksklusif sangat penting bagi tumbuh kembang anak. Penelitian yang dilakukan pada $20 \mathrm{ibu}$ yang mempunyai anak usia 0-24 bulan pengunjung Posyandu menunjukkan bahwa terdapat perbedaan motorik kasar antara anak yang diberikan ASI eksklusif dan tidak diberikan ASI eksklusif (Supriatin, 2019).

Social Cognitive Theory menjelaskan bahwa perilaku manusia dipengaruhi oleh pengaruh pribadi serta pengaruh lingkungan yang saling timbal balik. Perkembangan anak sangatlah perlu diperhatikan, baik secara fisik maupun psikologis, semua ini dimulai sejak proses tumbuh dan kembang pada usia dini, terutama pada saat masa balita, hal ini bertujuan untuk membentuk kualitas SDM yang optimal dalam membangun bangsa kedepan. Salah satu upaya dalam membentuk perkembangan yang optimal sedini mungkin sangatlah tergantung pada pemberian ASI atau menyusui, karena ASI tidak hanya berfungsi dalam memberikan nutrisi bagi bayi, tetapi juga sangat mempunyai arti dalam perkembangan anak karena seolah-olah hubungan anak ibu tidak terputus begitu dia dilahirkan ke dunia (Damayanti \& Sanjaya, 2019).

Penelitian tentang perilaku ibu menyusui sudah pernah dilakukan, namun penelitian ini berfokus pada self efficacy, outcome expectations, socio structural factors dan intention terhadap perilaku ibu. 


\section{METODE PENELITIAN}

Jenis penelitian yang digunakan yakni penelitian kuantitatif dengan desain analitik observasional, sampel penelitian ini sebanyak 81 ibu yang memiliki bayi berumur 6-12 bulan di wilayah kerja Puskesmas Blabak Kabupaten Kediri. Pengambilan sampel dilakukan dengan simple random sampling. Pada penelitian ini data primer didapatkan dengan dengan metode wawancara menggunakan kuesioner sedangkan data sekunder berupa laporan capaian pemberian ASI Eksklusif yang dimiliki oleh Puskesmas Blabak dan Dinas Kesehatan Kabupaten Kediri. Data diolah menggunakan SPSS. Kaji etik dalam penelitian ini dilakukan oleh Komite Etik Penelitian Kesehatan Fakultas Kesehatan Masyarakat Universitas Airlangga.

\section{HASIL PENELITIAN}

Tabel. 1

Perilaku Ibu, Self Efficacy dan Outcome Expectation dalam Pemberian ASI pada Responden Ibu Bayi (6-12 Bulan)

\begin{tabular}{lcc}
\hline Variabel & Jumlah (n) & $\%$ \\
\hline Pemberian Asupan pada Bayi & & \\
\hline ASI saja & 46 & 56,8 \\
ASI dan susu formula & 26 & 32,1 \\
Susu formula saja & 1 & 1,2 \\
ASI dan pisang & 4 & 4,9 \\
ASI dan air putih & 4 & 4,9 \\
\hline Perilaku Ibu Bayi (6-12 bulan) dalam Pemberian ASI Eksklusif & \\
\hline Tidak Eksklusif & 35 & 43,2 \\
Eksklusif & 46 & 56,8 \\
\hline Tingkat Self Efficacy Ibu Bayi (6-12 bulan) & & \\
\hline Rendah & 0 & 0,0 \\
Sedang & 51 & 63,0 \\
Tinggi & 30 & 37,0 \\
\hline Physical Outcome & & \\
\hline Rendah & 0 & 0,0 \\
Sedang & 33 & 40,7 \\
Tinggi & 48 & 59,3 \\
\hline Social Reaction & & \\
\hline Rendah & 0 & 0,0 \\
Sedang & 44 & 55,6 \\
Tinggi & 45 & 44,4 \\
\hline Self Evaluative Ibu Bayi (6-12 bulan) & 36 & \\
\hline Rendah & & \\
Sedang & 0 & \\
Tinggi & & \\
\hline & & \\
\hline
\end{tabular}




\begin{tabular}{|c|c|c|}
\hline Variabel & Jumlah (n) & $\%$ \\
\hline \multicolumn{3}{|c|}{ Tingkat Outcome Expectation Ibu Bayi (6-12 bulan) } \\
\hline Rendah & 0 & 0,0 \\
\hline Sedang & 30 & 37,0 \\
\hline Tinggi & 51 & 63,0 \\
\hline \multicolumn{3}{|c|}{$\begin{array}{l}\text { Kategori Facilitators dan Impediment Petugas } \\
\text { Kesehatan Terkait ASI Eksklusif }\end{array}$} \\
\hline Tidak Mendukung & 26 & 32,1 \\
\hline Mendukung & 55 & 67,9 \\
\hline \multicolumn{3}{|c|}{$\begin{array}{l}\text { Kategori Facilitators dan Impediment Suami Terkait } \\
\text { ASI Eksklusif }\end{array}$} \\
\hline Tidak Mendukung & 10 & 12,3 \\
\hline Mendukung & 71 & 87,7 \\
\hline \multicolumn{3}{|c|}{$\begin{array}{l}\text { Kategori Facilitators dan Impediment Orang } \\
\text { Tua/Mertua Terkait ASI Eksklusif }\end{array}$} \\
\hline Tidak Mendukung & 20 & 24,7 \\
\hline Mendukung & 61 & 75,3 \\
\hline \multicolumn{3}{|c|}{$\begin{array}{l}\text { Kategori Facilitators dan Impediment Lingkungan } \\
\text { Terkait ASI Eksklusif }\end{array}$} \\
\hline Tidak Mendukung & 5 & 6,2 \\
\hline Mendukung & 76 & 93,8 \\
\hline \multicolumn{3}{|c|}{ Sociostructural Factors Ibu Bayi (6-12 bulan) } \\
\hline Tidak Mendukung & 11 & 13,6 \\
\hline Mendukung & 70 & 86,4 \\
\hline \multicolumn{3}{|c|}{$\begin{array}{l}\text { Intention Ibu Bayi (6-12 bulan) dalam Pemberian } \\
\text { ASI }\end{array}$} \\
\hline Tidak Eksklusif & 15 & 18,5 \\
\hline Eksklusif & 66 & 81,5 \\
\hline
\end{tabular}

Berdasarkan tabel 1 dapat diperoleh informasi bahwa perilaku pemberian ASI merupakan praktik responden ibu bayi (6-12 bulan) di wilayah kerja Puskesmas Blabak Kabupaten Kediri dalam memberikan ASI kepada bayinya yaitu perilaku pemberian ASI secara eksklusif 65 orang $(56,8 \%)$ dan ibu yang melakukan perilaku pemberian ASI tidak eksklusif memiliki jumlah yang cukup besar yakni 35 orang atau 43,2\%. Self efficacy merupakan kepercayaan diri ibu untuk mewujudkan suatu perilaku pemberian ASI secara eksklusif. mayoritas responden ibu bayi (6-12 bulan) memiliki tingkat self efficacy yang sedang yakni sebesar $63,0 \%$. Outcome expectation merupakan harapan ibu terhadap hasil yang akan diterima ketika memberikan ASI eksklusif kepada bayi usia 0-6 bulan. Outcome expectation dalam penelitian ini dapat dilihat melalui 3 bentuk yakni physical outcome, social reaction dan self evaluative. Outcome expectation dalam kategori tinggi yakni sebanyak 50 orang atau $63,0 \%$. Tidak ada responden yang memiliki outcome expectation pada kategori rendah. 
Tabel. 2

Pengaruh Self Efficacy, Outcome Expectation dan Sociostructural Factors terhadap Intention Ibu dalam Perilaku Pemberian ASI

\begin{tabular}{clccc}
\hline No. & \multicolumn{1}{c}{ Variabel } & $\operatorname{Exp}(\beta)$ & Signifikansi $(p)$ & Keterangan \\
\hline 1. & Self Efficacy & 1,933 & 0,34 & $\begin{array}{c}\text { Tidak Signifikan } \\
\text { Berpengaruh }\end{array}$ \\
2. & Outcome Expectation & 1,277 & 0,682 & $\begin{array}{c}\text { Tidak Signifikan } \\
\text { Berpengaruh }\end{array}$ \\
3. & $\begin{array}{l}\text { Socio-structural } \\
\text { Factors }\end{array}$ & 2,99 & 0,016 & $\begin{array}{c}\text { Signifikan } \\
\text { Berpengaruh }\end{array}$ \\
\hline
\end{tabular}

Berdasarkan tabel 2 dapat diketahui bahwa self efficacy tidak berpengaruh signifikan terhadap intention responden untuk memberikan ASI eksklusif kepada bayinya. Uji pengaruh outcome expectation terhadap intention responden dalam pemberian ASI juga menunjukkan hasil yang tidak signifikan. Penelitian ini menunjukkan sociostructural factors memiliki pengaruh yang signifikan terhadap intention ibu dalam pemberian ASI yakni dengan $p=0,016$ dengan $\operatorname{Exp}(\mathrm{B})$ sebesar 2,990. Hasil uji pengaruh tersebut memberikan arti bahwa kemungkinan responden yang memiliki sociostructural factors akan mempunyai intention memberikan ASI secara eksklusif 2,990 kali lebih besar dibandingkan dengan kelompok responden yang tidak memiliki dukungan sociostructural factors.

Tabel. 3

Pengaruh Self Efficacy, Outcome Expectation dan Intention terhadap Perilaku Ibu dalam Pemberian ASI Eksklusif

\begin{tabular}{|c|c|c|c|c|}
\hline No. & Variabel & $\operatorname{Exp}(\beta)$ & Signifikansi (p) & Keterangan \\
\hline 1. & $\begin{array}{c}\text { Self } \\
\text { Efficacy }\end{array}$ & 0,561 & 0,294 & $\begin{array}{c}\text { Tidak Signifikan } \\
\text { Berpengaruh }\end{array}$ \\
\hline 2. & $\begin{array}{c}\text { Outcome } \\
\text { Expectation }\end{array}$ & 0,759 & 0,586 & $\begin{array}{c}\text { Tidak Signifikan } \\
\text { Berpengaruh }\end{array}$ \\
\hline 3. & Intention & 3,527 & $0,003 *$ & $\begin{array}{c}\text { Signifikan } \\
\text { Berpengaruh }\end{array}$ \\
\hline
\end{tabular}

Berdasarkan tabel 3 uji pengaruh self efficacy terhadap perilaku pemberian ASI pada tabel 3 tidak menunjukkan hasil yang signifikan yakni $\mathrm{p}=0,294$. Outcome expectation responden ibu bayi (6-12 bulan) di wilayah kerja Puskesmas Blabak Kabupaten Kediri tidak berpengaruh secara signifikan terhadap perilaku pemberian ASI yakni $\mathrm{p}=0,586$. Intention responden berpengaruh secara signifikan terhadap perilaku pemberian ASI yakni $\mathrm{p}=0,003$ dengan $\operatorname{Exp}(B)=3,527$.

\section{PEMBAHASAN}

Pengaruh Self Efficacy, Outcome Expectation dan Sociostructural Factors terhadap Intention Ibu Bayi (6-12 Bulan) tidak berpengaruh signifikan terhadap intention responden untuk memberikan ASI eksklusif kepada bayinya. Hal ini tidak sejalan dengan penelitian Wibowo et al., (2019) yang menyatakan bahwa pentingnya kompetensi nenek dalam pemberian ASI juga sangat berpengaruh terhadap keberhasilan pemberian ASI oleh ibu kepada bayinya. Keluarga adalah unit terkecil dari suatu masyarakat yang memiliki peran sosial masing-masing yang mempunyai tujuan menciptakan dan mempertahankan budaya serta meningkatkan perkembangan fisik, psikologis, dan sosial anggota keluarga yang lain. Anggota keluarga sangat besar pengaruhnya pada anggota keluarga yang lain. Salah satunya 
adalah nenek. Self efficacy dipengaruhi pengalaman pribadi yang telah dilalui secara nyata berupa keberhasilan dan kegagalan. Seorang nenek yang mempunyai pengalaman saat merawat anaknya dapat memberikan ASI eksklusif akan meningkatkan self efficacy dalam memberikan pendampingan kepada anaknya (ibu yang sedang menyusui) agar anaknya memberikan ASI eksklusif dengan jumlah anak lebih dari satu dan usia cucu lebih dari 6 bulan akan membuat seorang nenek mempunyai self efficacy yang baik. Selain pengalaman self efficacy dapat ditingkatkan melalui verbal persuasion yang dapat dilakukan berulang.

Penelitian yang dilakukan oleh Muharyani et al., (2018) menjelaskan bahwa lingkungan sekitar ibu dalam hal ini suami, keluarga dan tenaga kesehatan selayaknya menjadi support system terbesar bagi ibu dalam menyusui bayinya. Kurniawati et al., (2020) dalam penelitiannya menjelaskan bahwa dukungan keluarga mempunyai peran penting dalam menunjang keberhasilan ibu dalam pemberian ASI eksklusif. Dengan dukungan keluarga yang baik maka perilaku ibu dalam pemberian ASI eksklusif juga baik, dukungan keluarga yang diberikan kepada ibu akan mempengaruhi kondisi psikologis ibu, sehingga ibu akan mempunyai motivasi yang kuat untuk berusaha mempraktekkan bagaimana menyusui yang benar dan tepat selama 6 bulan. Self efficacy merupakan keyakinan individu terhadap kemampuannya untuk mengatur dan melaksanakan tindakan agar tercapai tujuan yang ditetapkan. Self efficacy juga berusaha untuk menilai keyakinan dan kemampuannya secara individu, agar dapat tercapai apa yang menjadi tujuan.

Uji pengaruh self efficacy terhadap perilaku pemberian ASI tidak menunjukkan hasil yang signifikan yakni $\mathrm{p}=0,294$. Hal tersebut tidak sejalan dengan penelitian Pramanik et al., (2020) yang menjelaskan bahwa tingkat self-efficacy ibu menyusui yang rendah mempunyai kontribusi terhadap tidak tercapainya pemberian ASI eksklusif pada bayinya, dimana faktor yang mempengaruhi terhadap tingkat pemberian ASI Eksklusif. Oleh karena itu, perlu adanya beberapa upaya yang dilakukan untuk berbagi pengalaman dalam membentuk dan meningkatkan kepercayaan diri dalam memberikan ASI eksklusif pada bayinya. Menurut (Muyassaroh et al., 2020) Faktor yang dapat mendukung tindakan menyusui antara lain adalah keyakinanan diri bahwa mampu untuk menyusui secara efektif. Efikasi diri merupakan sejauh mana seseorang memperkirakan kemampuan dirinya dalam melaksanakan tugas atau melakukan suatu tugas yang diperlukan untuk mencapai suatu hasil tertentu. Keyakinan tersebut meliputi kepercayaan diri, kemampuan menyesuaikan diri, kapasitas kognitif, kecerdasan dan, kapasitas bertindak pada situasi yang penuh tekanan.

\section{SIMPULAN}

Faktor yang mempengaruhi intention responden dalam pemberian ASI ekslusif yakni hanya sociostructural factors. Sedangkan self efficacy dan outcome expectation tidak bepengaruh terhadap intention ibu dalam pemberian ASI eksklusif. Faktor yang mempengaruhi perilaku responden dalam pemberian ASI, ekslusif yakni hanya intention Sedangkan self efficacy dan outcome expectation tidak berpengaruh terhadap perilaku ibu dalam pemberian ASI eksklusif.

\section{SARAN}

\section{Bagi Puskesmas Blabak Kediri}

Untuk meningkatkan capaian ASI eksklusif di Puskesmas Blabak Kabupaten Kediri perlu dilakukan yaitu kader mengingatkan ibu bayi untuk memberikan ASI secara ekslusif saat Posyandu sesuai yang tertera dalam Kartu Menuju Sehat (KMS), Bidan desa melakukan monitoring terhadap kerja kader dalam mengingatkan ibu bayi untuk memberikan ASI secara eksklusif. Bidan melakukan edukasi untuk meningkatkan pemahaman ibu hamil tentang 
manfaat dan pentingnya ASI eksklusif sehingga ibu bayi dapat memberi pemahaman kepada orang tua atau mertua sehingga dapat menolak apabila orang tua atau mertua menyuruh untuk memberikan makanan atau minuman lain selain ASI kepada bayi usia 0 sampai 6 bulan.

\section{Bagi Peneliti selanjutnya}

Penelitian selanjutnya dapat menggali dan meneliti pengaruh variabel lain, sehingga dapat dihasilkan model penelitian yang lebih spesifik lagi untuk mengetahui faktor yang mempengaruhi perilaku ibu dalam pemberian ASI ekslusif.

\section{DAFTAR PUSTAKA}

Damayanti, N., \& Sanjaya, I. G. A. (2019). Karakteristik Pertumbuhan dan Perkembangan Balita yang Tidak Mendapatkan ASI Eksklusif pada Usia 24 Bulan di wilayah kerja Puskesmas Mabelopura. Jurnal Medika Askhairaat, 1(1), 21-27. http://jurnal.fkunisa.ac.id/index.php/MA/article/view/24

Kemenkes, R. (2017). Profil Kesehatan Indonesia 2016 dan Informasi Kesehatan

Kurniawati, R., Sari, W. I., \& Islamiah, D. (2020). Hubungan antara Dukungan Keluarga dengan Perilaku Ibu dalam Pemberian ASI Eksklusif DI Desa Trenyang Wilayah Kerja Puskesmas Sumberpucung. Borneo Journal of Medical Laboratory Technology, 2(2), 155-160. https://doi.org/10.33084/bjmlt.v2i2.1389

Muharyani, P. W., Maulida, M. N., Rivani, E., \& Agustarini, A. (2018). Dukungan Suami, Keluarga dan Tenaga Kesehatan dalam Pemberian ASI Eksklusif pada Bayi. Proceeding Seminar Nasional Keperawatan, 4(1), 215-219. http://conference.unsri.ac.id/index.php/SNK/article/view/1216

Muyassaroh, Y., Octavianingrum, D. A., \& Ayuningtiyas, A. (2020). Pengaruh Modul Manajemen Laktasi terhadap Efikasi Diri dan Keberhasilan Menyusui. Jurnal Darul Azhar, $8(1), \quad$ 129-137. http://jurnalkesehatan.id/index.php/JDAB/article/view/156

Pramanik, Y. R., Sumbara, S., \& Sholihatul, R. (2020). Hubungan Self-Efficacy Ibu Menyusui dengan Pemberian Asi Ekslusif. Jurnal Ilmiah Kesehatan Iqra, 8(1), 39-44. https://doi.org/10.1234/jiki.v8i1.169

Sari, W. A., \& Farida, S. N. (2020). Hubungan Pengetahuan Ibu Menyusui tentang Manfaat ASI dengan Pemberian ASI Eksklusif Kabupaten Jombang. Jurnal

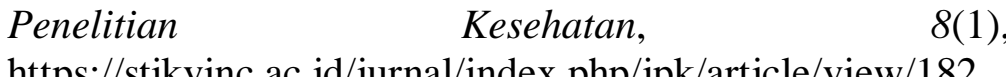
https://stikvinc.ac.id/jurnal/index.php/jpk/article/view/182

Supriatin, W. (2019). Pemberian ASI Eksklusif terhadap Kemampuan Motorik Kasar Anak Usia 0-24 Bulan. Seminar Nasional PGPAUD. http://semnaspgpaud.untirta.ac.id/index.php/semnas2017/article/view/79

Valizadeh, S., Hosseinzadeh, M., Mohammadi, E., Hassankhani, H., Fooladi, M. M., \& Cummins, A. (2018). Coping Mechanism Against High Levels of Daily Stress by Working Breastfeeding Mothers in Iran. International Journal of Nursing Sciences, 5(1), 39-44. https://doi.org/10.1016/j.ijnss.2017.12.005

WHO. (2017). WHO | 10 facts on breastfeeding. WHO. https://www.who.int/features/factfiles/breastfeeding/facts/en/

Wibowo, H., Probowati, R., Muhith, A., Savitri, M., \& Khamidah, K. (2019). Self Efficacy Nenek dalam Pemberian ASI eklusif pada Ibu Menyusui Bayi usia 1-6 Bulan dengan Pendekatan Health Promotion Model. Journal of Health Sciences, 12(2), 1-14. https://doi.org/10.33086/jhs.v12i02.892 